\title{
Correction to: Significant detection of new germline pathogenic variants in Australian Pancreatic Cancer Screening Program participants
}

Krithika Murali' ${ }^{1}$, Tanya M. Dwarte 2,3,4 Mehrdad Nikfarjam5, Katherine M. Tucker ${ }^{3,6}$, Rhys B. Vaughan', Marios Efthymiou ${ }^{7}$, Allison Collins ${ }^{8}$, Allan D. Spigelmann ${ }^{6,9}$, Lucinda Salmon ${ }^{1}$, Amber L. Johns ${ }^{2}$, David B. Williams ${ }^{4}$, Martin B. Delatycki ${ }^{1}$, Thomas John ${ }^{10}$ and Alina Stoita ${ }^{6,4^{*}}$

\section{Correction to: Hered Cancer Clin Pract 19, 33 (2021) https://doi.org/10.1186/s13053-021-00190-1}

Following publication of the original article [1], an error was identified in affiliation 6 . The correct affiliation 6 is:

University of New South Wales, St Vincent's Clinical School and Prince of Wales Clinical School, Randwick, NSW 2031, Australia

The original article [1] has been corrected.

\section{Author details}

'Department of Clinical Genetics, Austin Health, Heidelberg, VIC 3084, Australia. ${ }^{2}$ Australian Pancreatic Cancer Genome Initiative, Garvan Institute of Medical Research, Darlinghurst, NSW 2010, Australia. ${ }^{3}$ Hereditary Cancer Centre, Prince of Wales Hospital, Randwick, NSW 2031, Australia. ${ }^{4}$ Department of Gastroenterology, St Vincent's Hospital, Darlinghurst, NSW 2010, Australia. ${ }^{5}$ Division of Surgery, Austin Health, Heidelberg, VIC 3084, Australia.

${ }^{6}$ University of New South Wales, St Vincent's Clinical School and Prince of Wales Clinical School, Randwick, NSW 2031, Australia. ${ }^{7}$ Department of Gastroenterology, Austin Health, Heidelberg, VIC 3084, Australia. ${ }^{8}$ Clinical Trials Unit, Olivia Newton John Cancer and Wellness Centre, Austin Health, Heidelberg, VIC 3084, Australia. ${ }^{9}$ Cancer Genetics Unit, The Kinghorn Cancer Centre, St Vincent's Hospital, Darlinghurst, NSW 2010, Australia. ${ }^{10}$ Peter MacCallum Cancer Centre, Parkville, VIC 3000, Australia.
Published online: 08 September 2021

\section{Reference}

1. Murali K, Dwarte TM, Nikfarjam M, et al. Significant detection of new germline pathogenic variants in Australian Pancreatic Cancer Screening Program participants. Hered Cancer Clin Pract. 2021;19:33 https://doi.org/1 0.1186/s13053-021-00190-1.

The original article can be found online at https://doi.org/10.1186/s13053021-00190-1.

* Correspondence: alina.stoita@svha.org.au

שUniversity of New South Wales, St Vincent's Clinical School and Prince of Wales Clinical School, Randwick, NSW 2031, Australia

${ }^{4}$ Department of Gastroenterology, St Vincent's Hospital, Darlinghurst, NSW 2010, Australia

Full list of author information is available at the end of the article

C C The Author(s). 2021 Open Access This article is licensed under a Creative Commons Attribution 4.0 International License, which permits use, sharing, adaptation, distribution and reproduction in any medium or format, as long as you give appropriate credit to the original author(s) and the source, provide a link to the Creative Commons licence, and indicate if changes were made. The images or other third party material in this article are included in the article's Creative Commons licence, unless indicated otherwise in a credit line to the material. If material is not included in the article's Creative Commons licence and your intended use is not permitted by statutory regulation or exceeds the permitted use, you will need to obtain permission directly from the copyright holder. To view a copy of this licence, visit http://creativecommons.org/licenses/by/4.0/ The Creative Commons Public Domain Dedication waiver (http://creativecommons.org/publicdomain/zero/1.0/) applies to the data made available in this article, unless otherwise stated in a credit line to the data. 